\title{
Pengaruh Keterampilan Kerja Dan Fasilitas Terhadap Produktivitas Kerja Persatuan Nelayan Kampung Bugis Kota Tanjungpinang
}

\author{
Nurhasanah \\ Program Studi Manajemen, Fakultas Ekonomi, Universitas Maritim Raja Ali Haji, \\ Tanjungpinang, Kepulauan Riau, Indonesia
}

\begin{abstract}
ABSTRAK : Penelitian ini bertujuan untuk mengetahui pengaruh keterampilan kerja,fasilitas kerja terhadap produktivitas kerja Persatuan Nelayan Kampung Bugis Kota Tanjungpinang.Penelitian ini menggunakan jenis penelitian kuantitatif.Populasi dalam penelitian ini adalah nelayan yang tergabung dalam persatuan nelayan Kampung Bugis.Teknik pengambilan sampel yang digunakan adalah simple random sampling.Sampel dalam penelitian ini berjumlah 41 orang.Data yang digunakan dalam penelitian ini adalah data primer yang diperoleh melalui kuesioner. Data yang terkumpul diuji dan dianalisis menggunakan program SPSS 24. Uji validitas instrumen menggunakan rumus Correclation Bivariate, sedangkan uji reliabilitas menggunakan Cronbach Alpha.Alat ukur terbukti valid dan reliabel untuk instrumen penelitian.Analisis regresi berganda digunakan untuk uji hipotesis penelitian ini.dimana Keterampilan Kerja $\left(\mathrm{X}_{1}\right)$, Fasilitas Kerja $\left(\mathrm{X}_{2}\right)$ dan Produktivitas Kerja (Y). Hasil pengujian secara parsial untuk variabel keterampilan kerja memiliki pengaruh signifikan terhadap produktivitas kerja.Untuk variabel fasilitas kerja secara parsial memiliki pengaruh signifikan terhadap produktivitas kerja. Variabel Keterampilan Kerja dan fasilitas secara parsial memiliki pengaruh signifikan terhadap produktivitas kerja. Hasil pengujian secara simultan variabel keterampilan kerja, fasilitas kerja mempunyai pengaruh signifikan terhadap produktivitas kerja.
\end{abstract}

Kata Kunci: Keterampilan Kerja,Fasilitas Dan Produktifitas Kerja

Email Address : Nurhasanah@ umrah.ac.id

\section{PENDAHULUAN \\ Latar Belakang}

Tingkat kesejahteraan nelayan sangat dipengaruhi oleh hasil tangkapannya.Jika hasil tangkapannya bagus, makaproduktivitas mereka juga baik,begitupula sebaliknya.Masalah perikanantangkap yang juga memengaruhiproduktivitas nelayan adalahtingginya harga bahan bakar, cuaca, sumberdaya yang dikeluarkan danharga ikan sebagai output dalamperikanan tangkap (Trimiati, 2018). Berdasarkan hasil wawancara yang penulis lakukan di Kelurahan Kampung Bugis menunjukkan bahwa hasil tangkapan ikan mengalami penurunan sehingga produktivitas pun ikut menurun. Hal ini terjadi karena cuaca yang buruk, selain itu wilayah tangkapan yang terbatas dan populasi ikan yang semakin berkurang juga memengaruhi hasil tangkapan ikan di wilayah tersebut sehingga nelayan harus memiliki keterampilan tersendiri agar hasil tangkapan meningkat.Namun, diduga adafaktor lain yang memengaruhi hasiltangkapan nelayandi Kelurahan Kampung Bugisseperti faktor fasilitas kerja. Produktivitas kerja dapat dicapai apabila tenaga kerja mempunyai keterampilan kerja yang dapat diterapkan dalam melakukan pekerjaannya sehari-hari.Disamping itu keterampilan sangat berperan penting di dalam melaksanakan tugas maupun pekerjaan dimana dengan adanya keterampilan maka seorang nelayan dapat melaksanakan tugas maupun pekerjaan dengan lancar dan dapat menghindarkan kesalahan-kesalahan yang 
terjadi pada proses pelaksanaan pekerjaan atau tugas yang pada akhirnya mampu mendorong produktivitas kerja nelayan itu sendiri (Sari 2016). Berdasarkan penelitian yang dilakukan Ulum dkk (2018) menunjukkan hasil bahwa keterampilan kerja mempunyai pengaruh paling dominan terhadap produktivitas kerja karyawan pada pabrik rokok Gagak Hitam Kecamatan Maesan Kabupaten Bondowoso.

Menurut Rehman dan Mughal (International Journal of Economic, 2013), dalam penelitiannya menunjukkanbahwa meskipun tenaga kerja terampil meningkatkan produktivitas kerja secara keseluruhan secara positif dan di sisi lain tenaga kerja tidak terampil tidak meningkatkan produktivitas tenaga kerja secara keseluruhan. Tetapi kedua variabel independen (tenaga kerja terampil dan tidak terampil) tersebut secara bersama-sama meningkatkan produktivitas tenaga kerja secara keseluruhan dalam kasus ekonomi Pakistan.

Keterampilan kerja secara teknis berhubungan dengan fasilitas kerja, yaitu mampu mengoperasikan setiap peralatan yang digunakan dalam bekerja.Dengan adanya keterampilan kerja maka nelayan mampu menggunakan fasilitas kerja dalam menyelesaikan tugas dan pekerjaannya secara efisien.Berdasarkan hasil penelitian dari Sayoto dan Winarto (2018) dengan judul "Pengaruh Disiplin Kerja dan Fasilitas Kerja Terhadap Produktivitas Kerja Karyawan Mnctv Bagian Produksi” menunjukkan bahwa fasilitas kerja berpengaruh positif dan signifikan secara parsial terhadap produktivitas kerja karyawan.

Ketersediaan fasilitas-fasilitas mampu menambah semangatdan kegairahan kerja.Adanyarasa semangat di dalam melaksanakan pekerjaan dapat mendorong nelayan untuk bekerja secara lebih baik dan lebih produktif, sehingga produktivitas kerja nelayan meningkat.Sesuai dengan penelitian yang telah dilakukan oleh Assagaf dan Dotulong (2015), menunjukkan bahwa semangat kerja secara parsial berpengaruh signifikan terhadap produktivitas kerja pegawai Dinas Pendapatan Daerah Kota Manado.

Berdasarkan fenomena dan hasil penelitian terdahulu yang penulis uraikan di atas, diprediksikan bahwa ada permasalahan dalam produktivitas kerja sehingga penulis tertarik memilih judul "Pengaruh Keterampilan Kerja, Fasilitas Terhadap Produktivitas Kerja Persatuan Nelayan Kampung Bugis Kota Tanjungpinang”.

\section{Identifikasi Masalah}

Berdasarkan latar belakang dan judul penelitian yang telah dipaparkan di atas, maka dapat diambil kesimpulan bahwa identifikasi masalah dalam penelitian ini adalah yang berkaitan dengan keterampilan kerja, fasilitas kerja dan semangat kerja terhadap produktivitas kerja.

\section{Perumusan Masalah}

Dari latar belakang masalah yang telah penulis sajikan di atas, maka penulis merumuskan masalahmasalah yang terkandung adalah sebagai berikut:

1) Apakah keterampilan kerja berpengaruh terhadap produktivitas kerja?

2) Apakah fasilitas berpengaruh terhadap produktivitas kerja?

3) Apakah keterampilan kerja dan fasilitas berpengaruh terhadap produktivitas kerja?

\section{Pembatasan Masalah}

Agar penelitian ini dapat dilakukan secara fokus maka penulis memandang permasalahan penelitian yang diangkat perlu dibatasi variabelnya. Oleh sebab itu, penulis hanya melakukan penelitian yang berkaitan dengan "Keterampilan Kerja dan Fasilitas Terhadap Produktivitas Kerja Persatuan Nelayan Kampung Bugis". Produktivitas kerja nelayan dipilih karena peningkatan produktivitas kerja nelayan 
merupakan basis penggerak roda ekonomi yang penting bagi masyarakat kawasan pesisir dalam hal sumber mata pencaharian dan memberikan pendapatan secara langsung bagi para nelayan.

\section{Tujuan Penelitian}

Tujuan penelitian merupakan jawaban atau sasaran yang ingin dicapai penulis dalam sebuah penelitian. Oleh sebab itu, tujuan penelitian ini adalah:

1) Untuk mengetahui pengaruh keterampilan kerja terhadap produktivitas kerja.

2) Untuk mengetahui pengaruh fasilitas terhadap produktivitas kerja.

3) Untuk mengetahui pengaruh keterampilan kerja dan fasilitas terhadap produktivitas kerja.

\section{Manfaat Penelitian}

Adapun manfaat yang diharapkan dari penelitian ini adalah sebagai berikut:

1) Bagi penulis, penelitian ini dapat menjadi media penerapan pengetahuan yang selama ini diperoleh dan untuk mengetahui bagaimana fakta di lapangan tentang produktivitas kerja nelayan.

2) Bagi para nelayan, penelitian ini dapat dijadikan acuan untuk lebih memahami dan memikirkan cara kerja yang efektif untuk meningkatkan produktivitas kerja nelayan dan demi kesejahteraan para nelayan.

\section{TINJAUAN PUSTAKA}

\section{Keterampilan Kerja}

Menurut As'ad dalam Syahdan (2017: 3), keterampilan kerja berhubungan erat dengan kemampuan fisik dan mental yang dimiliki setiap orang untuk melaksanakan tugas sumber daya manusia (SDM). Sedangkan menurut Wahyudi dalam Syahdan (2017: 3) keterampilan kerja adalah kecakapan atau keahlian untuk melakukan suatu pekerjaan hanya diperoleh dalam praktek yang bisa dikuasai melalui pembelajaran dan bisa ditingkatkan melalui pembelajaran dan bantuan orang lain. Sehingga keterampilan kerja merupakan hal yang bersifat individual setiap individu akan memiliki tingkat keterampilan yang berbeda tergantung pada kemampuan dan pengalamannya. Dari pendapat ini dapat dikatakan bahwa keterampilan itu tidak bersifat turunan namun bisa diasah dengan pelatihan-pelatihan maupun pembelajaran melalui bantuan orang lain.

Menurut Moeheriono dalam Wiranti (2016: 98), keterampilan kerja didefinisikan sebagai kemampuan melaksanakan pekerjaan berdasarkan juklak/juknis atau instruksi dari atasan.Keterampilan kerja memiliki manfaat yang besar bagi individu, perusahaan dan masyarakat.Bagi individu keterampialn kerja dapat meningkatkan prestasinya sehingga memperoleh balas jasa yang sesuai dengan prestasinya.

\section{Hubungan Keterampilan Kerja Terhadap \\ Produktivitas Kerja}

Produktivitas kerja dan keterampilan kerja merupakan dua hal yang saling berhubungan.Menurut Rank dan Frese dalam Syahdan (2017)keterampilan kerja karyawan dalam melaksanakan tugas pada sebuah organisasi sangatlah penting peranannya. Seorang karyawan yang memiliki keterampilan kerja lebih baik tentu akan lebih mengerti apa yang harus dilakukan ketika menghadapi sebuah masalah yang muncul sehingga produktivitas dapat meningkat.

\section{Indikator Keterampilan Kerja}

Robbins dalam Ibrahim(2018) mengatakan keterampilan dibagi menjadi 4 kategori, yaitu :

1) Basic Literacy Skill(keterampilan dasar): Keahlian dasar yang sudah pasti harus dimiliki oleh setiap orang seperti membaca, menulis, berhitung serta mendengarkan.

2) Technical Skill (keterampilan teknis): Keahlian secara teknis yang didapat melalui pembelajaran 
dalam bidang teknik seperti mengoperasikan kompter dan alat digital lainnya.

3) Interpersonal Skill(keterampilan interpersonal): Keahlian setiap orang dalam melakukan komunikasi satu sama lain seperti mendengarkan seseorang, memberi pendapat dan bekerja secara tim.

\section{Problem Solving(penyelesaian masalah):}

Keahlian seseorang dalam memecahkan masalah dengan menggunakan logika atau perasaanya.

\section{Fasilitas}

Menurut Buchari dalam Setiyaningrum (2017: 17) fasilitas adalah penyedia perlengkapanperlengkapan fisik untuk memberikan kemudahan kepada penggunanya, sehingga kebutuhan-kebutuhan dari pengguna fasilitas tersebut dapat terpenuhi.

\section{Karakteristik Fasilitas Kerja}

Menurut Hartanto dalam Setiyaningrum (2017: 18) karakteristik dari sarana pendukung dalam proses aktivitas perusahaan adalah:

1) Mempunyai bentuk fisik.

2) Dipakai atau digunakan secara aktif dalam kegiatan normal perusahaan.

3) Mempunyai jangka waktu kegunaan relative permanen lebih dari satu periode akuntansi atau lebih dari satu bulan.

4) Memberikan manfaat di masa yang akan datang.

\section{Indikator Fasilitas Kerja}

Indikator fasilitas kerja harus sesuai dengan apa yang dibutuhkan karyawan dengan tujuan untuk meningkatkan produktivitas kerjanya. Indikator fasilitas menurut Faisal dalam Setiyaningrum (2017) adalah:

1) Sesuai dengan kebutuhan.

2) Mampu mengoptimalkan hasil kerja.

3) Mudah dalam penggunaan.

4) Mempercepat proses kerja.

5) Penempatan ditata dengan benar
6) Keamanan kerja

\section{Produktivitas Kerja}

Menurut Sunyoto (2015: 36) secara filosofi, produktivitas merupakan sikap mental yang selalu berusaha dan mempunyai pandangan bahwa suatu kehidupan hari ini lebih baik dari hari kemarin dan hari esok lebih baik dari hari ini. Secara teknis, produktivitas merupakan perbandingan antara hasil yang dicapai dan keselurahan sumber daya yang dipergunakan, produktivitas tenaga kerja merupakan perbandingan antara hasil yang dicapai dengan pasar tenaga kerja per satuan waktu dan sebagai tolok ukur jika ekspansi dan aktivitas dari sikap sumber yang digunakan selama produktivitas berlangsung dengan membandingkan jumlah yang dihasilkan dengan setiap sumber yang digunakan. Jadi produktivitas kerja adalah ukuran yang menunjukkan pertimbangan antara input dan output yang dikeluarkan perusahaan serta peran tenaga kerja yang dimiliki perusahaan.

\section{Indikator Produktivitas Kerja}

Menurut Simamora dalam Hartatik (2014: 218), bila suatu organisasi mengabaikan pengembangan sumber daya manusia, akan berakibat pada turunnya semangat kerja dan produktivitas pegawai. Adapun indikator produktivitas kerja yang akan timbul tersebut adalah sebagai berikut:

1) Kualitas kerja, dalam kegiatan menghasilkan produk, perusahaan berusaha agar produk tersebut mempunyai kualitas yang baik. Sebab, apabila produk yang dihasilkan kurang baik, produktivitas karyawan pun akan menurun.

2) Kuantitas kerja atau tingkat perolehan hasil, telah dijelaskan sebelumnya bahwa produktivitas adalah kemampuan seseorang dalam menghasilkan barang atau jasa. Berdasarkan dari pendapat tersebut, dengan adanya produktivitas kerja pegawai yang 
rendah, otomatis hasil produksi barang atau jasa akan menurun, sehingga target tidak tercapai.

3) Ketepatan waktu, kegiatan proses produksi memerlukan waktu yang cukup. Sebab, apabila waktu yang diberikan untuk menghasilkan produk kurang, yang dihasilkan juga sedikit, sehingga target produksi tidak tercapai.

4) Tingkat kesalahan, salah satu penyebab dari turunnya produktivitas pegawai dalam menghasilkan produk adalah tingkat kesalahan. Sebab, apabila tingkat kesalahan tinggi, produktivitas akan rendah.

5) Tingkat absensi, tinggi rendahnya tingkat absensi dari pegawai yang ada akan langsung berpengaruh terhadap produktivitas, karena pegawai yang tidak masuk kerja tidak akan produktif. Dengan demikian, hasil produksinya rendah. Akibatnya, target produksi yang telah ditetapkan tidak tercapai.

\section{Kerangka Pemikiran}

Penelitian ini dilakukan untuk menguji ada atau tidaknya pengaruh keterampilan kerjadan , fasilitas kerja terhadap produktivitas kerja nelayan. Adapun kerangka pemikiran tersebut dapat digambarkan sebagai berikut:

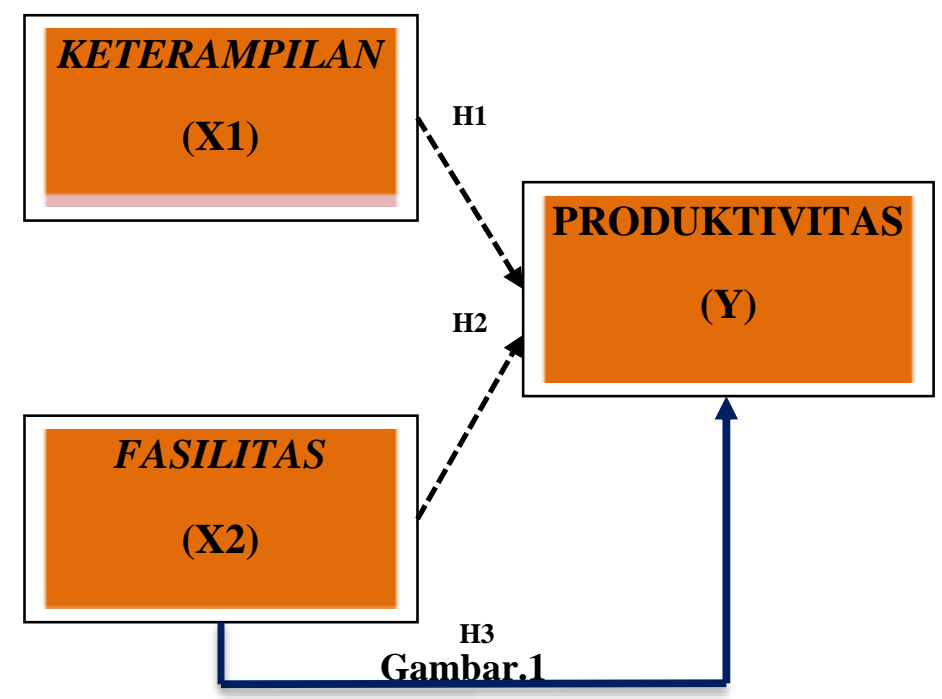

Kerangka Pemikiran

\section{METODOLOGI PENELITIAN}

Dalam penelitian ini, penulis menggunakan metode penelitian kuantitatif. Sugiyono (2017: 8) mengemukakan bahwa metode penelitian kuantitatif dapat di artikan sebagai metode penelitian yang berlandaskan pada filsafat positivisme, digunakan untuk meneliti pada populasi atau sampel tertentu, pengumpulan data menggunakan instrumen penelitian, analisis data bersifat kuantitatif statistik, dengan tujuan untuk menguji hipotetis yang telah ditetapkan. Menurut Sunyoto (2013: 26), analisis kuantitatif adalah analisis yang menggunakan rumus-rumus statistik yang disesuaikan judul penelitian dan rumusan masalah, untuk perhitungan angka-angka dalam rangka menganalisis data yang diperoleh.

\section{Metode Pengumpulan Data}

Dari segi cara atau metode pengumpulan data, maka metode pengumpulan data dapat dilakukan dengan cara berikut ini:

1) Metode wawancara

Menurut Sunyoto (2017: 22), metode wawancara adalah metode pengumpulan data dengan mengajukan pertanyyaan-pertanyaan secara bebas baik terstruktur maupun tidak terstruktur dengan tujuan untuk memperoleh informasi secara luas mengenai objek penelitian. Metode wawancara memerlukan waktu relatif lebih lama.

2) Metode Observasi

Menurut Sugiyono (2017: 145), metode pengumpulan data dengan observasi digunakan apabila penelitian berkenaan dengan perilaku manusia, proses kerja, gejala-gejala alam dan bila responden yang diamati tidak terlalu besar.

3) Metode Kuesioner

Menurut Sunyoto (2013: 23) metode kuesioner adalah metode pengumpulan data dengan cara 
menggunakan daftar pertanyaan yang diajukan kepada responden untuk dijawab dengan memberikan angket.

\section{Teknik Penentuan Populasi dan Sampel}

Populasi

Menurut Sugiyono (2017:80), populasi adalah wilayah generalisasi yang terdiri atas obyek atau subyek yang mempunyai kualitas dan karakteristik tertentu yangditetapkan oleh peneliti untuk dipelajari dan kemudian ditarik kesimpulannya.

Populasi dalam penelitian ini adalahnelayan yang ada di Persatuan Nelayan Kampung Bugis dan berdasarkan data yang diperoleh dari Ketua nelayan setempat jumlah nelayan yang aktif yaitu berjumlah 70 orang.

\section{Sampel}

Menurut Sugiyono (2017: 81), sampel adalah bagian dari jumlah dan karakteristik yang dimiliki oleh populasi tersebut. Bila populasi besar, dan peneliti tidak mungkin mempelajari semua yang ada pada populasi, misalnya karena keterbatasan dana, tenaga dan waktu, maka peneliti dapat mennggunakan sampel yang diambil dari populasi itu. Apa yang dipelajari dari sampel itu, kesimpulannya akan dapat diberlakukan untuk populasi. Untuk itu sampel yang diambil dari populasi harus betul-betul respresentatif (mewakili).

Dalam penelitian ini, teknik pengambilan sampel yang penulis gunakan adalah simple Random Sampling, karena pengambilan anggota sampel dari populasi dilakukan secara acak tanpa memperhatikan strata yang ada dalam populasi itu.Agar sampel yang diperoleh representatif,maka penelitian ini menggunakan teknik penentuan ukuran sampel, yaitu teknik Solvin (dalam Siregar, 2014: 61) dengan rumus sebagai berikut:

$$
\begin{array}{ll}
n=\frac{\mathrm{N}}{1+\mathrm{Ne}^{2}} & \text { Keterangan: } \\
=\frac{70}{1+\left(70(0,1)^{2}\right)} & n: \text { jumlah sampel } \\
=41,1741 \longrightarrow & \mathrm{N} \text { : jumlah popula } \\
& 70 \text { orang } \\
& \text { e: batas toleransi } \\
& \text { kesalahan (error } \\
& \text { tolerance })=10 \%
\end{array}
$$

Maka diperoleh sampel sebanyak 41 orang sebagai responden.

\section{Metode Analisis}

Data yang terkumpul selanjutnya akan diuji dan dianalisis dengan program Statitical Product and Service Solution (SPSS) versi 24. Adapun data yang digunakan dalam penelitian ini adalah uji kualitas data, uji asumsi klasik, dan uji hipotesis.

\section{Uji Kualitas Data}

\section{Uji Validitas}

Menurut Ghozali (2013: 52), uji validitas digunakan untuk mengukur sah atau valid tidaknya suatu kuesioner. Suatu kuesioner dikatakan valid jika pertanyaan pada kuesioner mampu untuk mengungkapkan sesuatu yang akan diukur oleh kuesioner tersebut.

\section{Uji Reliabilitas}

Menurut Ghozali (2013:47), reliabilitas sebenarnya adalah alat untuk mengukur suatu kuesioner yang merupakan indikator dari variabel atau konstruk. Suatu kuesioner dikatakan reliabel atau handal jika jawaban seseorang terhadap pernyataan adalah konsisten atau stabil dari waktu ke waktu.Pengukuran reliabilitas dilakukan dengan Oneshot, yaitu pengukuran yang dilakukan sekali saja dan 
kemudianhasilnya dibandingkan dengan pertanyaan lain atau mengukur korelasi antar jawaban pertanyaan. Suatu konstruk atau variabel dikatakan reliabel jika memberikan nilai Cronbach Alpha > 0,70 (Nunnally dalam Ghozali, 2013:48).

\section{Uji Asumsi Klasik}

Uji asumsi klasik digunakan untuk menguji apakah model regresi benar-benar menunjukkan hubungan yang signifikan dan representatif. Ada tiga pengujian dalam uji asumsi klasik, yaitu:

\section{Uji Normalitas}

Menurut Ghozali (2013: 154), uji normalitas bertujuan untuk menguji apakah dalam model regresi, variabel pengganggu atau residual memiliki distribusi normal. Seperti diketahui bahwa uji $t$ dan uji $F$ mengasumsikan bahwa nilai residual mengikuti distribusi normal.Kalau asumsi ini dilanggar maka uji statistik menjadi tidak valid untuk jumlah sampel kecil.

\section{Uji Multikolonieritas}

Menurut Ghozali (2013:105), uji multikolonieritas bertujuan untuk menguji apakah pada model regresi ditemukan adanya korelasi antar variabel bebas (independen). Apabila terjadi korelasi, maka dinamakan terdapat problem multikolinearitas.

\section{Uji Heteroskedastisitas}

Menururt Ghozali (2013: 139), uji heteroskedastisitas bertujuan menguji apakah dalam model regresi terjadi ketidaksamaan variance dari residual satu pengamatan ke pengamatan yang lain. Jika variance dari residual satu pengamatan ke pengamatan lain tetap, maka disebut homoskedastisitas dan jika varians berbeda disebut heteroskedasitas. Model regresi yang baik adalah yang homoskedastisitas atau tidak terjadi heteroskedastisitas.

\section{Analisis Regresi Linier Berganda}

Menurut Siregar (2014: 405) regresi berganda merupakan pengembangan dari regresi linier sederhana, yaitu sama-sama alat yang dapat digunakan untuk melakukan prediksi permintaan di masa yang akan datang, berdasarkan data masa lalu atau untuk mengetahui pengaruh satu atau lebih variabel bebas terhadap satu variabel tak bebas. Penerapan metode regresi berganda jumlah variabel bebas yang digunakan lebih dari satu yang memengaruhi satu variabel tak bebas.

$$
\mathrm{Y}=\mathrm{a}+\mathrm{b} 1 \mathrm{x} 1+\mathrm{b} 2 \times 2+\mathrm{b3} \times 3+\mathrm{b} 4 \times 4+\mathrm{b} 5 \times 5+\mathrm{e}
$$

Keterangan:

$$
\begin{array}{ll}
\mathrm{Y} & =\text { variabel dependent } \\
\mathrm{b} 1, \mathrm{~b} 2, \mathrm{~b} 3, \mathrm{~b} 4 & =\text { koefisien garis regresi variabel bebas } \\
\mathrm{x} 1, \mathrm{x} 2, \mathrm{x} 3, \mathrm{x} 4 & =\text { Variabel independen } \\
\mathrm{a} & =\text { Konstanta } \\
\mathrm{e} & =\text { nilai } \text { eror } \text { atau (tingkat kesalahan) }
\end{array}
$$

\section{Uji Hipotesis}

\section{Uji t (Uji Parsial)}

Menurut Ghozali (2016: 97) menyatakan bahwa uji statistik $t$ pada dasarnya menunjukkan seberapa jauh pengaruh satu variabel penjelas atau independen secara individual dalam menerangkan variasi variabel dependen. Kriteria signifikansi parameter individual (uji statistik t) adalah:

1) Jika signifikansi $>0,05$ maka $\mathrm{H}_{0}$ diterima

2) Jika signifikansi $<0,05$ maka $\mathrm{H}_{0}$ ditolak

\section{Uji F (Uji Simultan)}

Menurut Ghozali (2016: 96) menyatakan bahwa uji statistik $\mathrm{F}$ pada dasarnya menunjukkan apakah secara varibel independen (bebas) yang dimasukkan dalam model mempunyai pengaruh secara bersamasama terhadap variabel dependen (terikat). Kriteria signifikan simultan adalah:

1) Tingkat signifikan 0,05 . 
2) Jika $\mathrm{F}$ hitung $>\mathrm{F}$ tabel, tingkat signifikan $<0,05$ maka $\mathrm{H}_{0}$ ditolak (ada pengaruh signifikan).

3) Jika $\mathrm{F}$ hitung $<\mathrm{F}$ tabel, tingkat signifikan $>0,05$ maka $\mathrm{H}_{0}$ diterima (tidak ada pengaruh signifikan).

\section{Koefisien Determinasi (Adjusted $\mathbf{R}^{2}$ )}

Menurut Ghozali (2016: 95) koefisien determinasi $\left(\mathrm{R}^{2}\right)$ pada intinya mengukur seberapa jauh kemampuan model dalam menerangkan variasi variabel dependen.Nilai koefisien determinasi adalah nol dan satu. Nilai $\mathrm{R}^{2}$ yang kecil berarti kemampuan variabelvariabel independen dalam menjelaskan variabel dependen amat jelas. Nilai yang mendekati satu berati variabel-variabel independen memberikan hampir semua informasi yang dibutuhkan untuk memprediksi variabel dependen.

\section{HASIL PENELITIAN DAN PEMBAHASAN}

\section{Gambaran Umum Responden}

Berdasarkan data kuesioner yang telah diisi oleh responden didapat data identitas responden yang memberikan gambaran tentang, usia, pendidikan, dan lama bekerja. Gambaran umum responden dapat dijelaskan sebagai berikut:

\section{Data Responden Berdasarkan Pendidikan}

\section{Tabel 1}

Data Responden Berdasarkan Pendidikan

\begin{tabular}{|c|c|c|}
\hline Pendidikan & Jumlah & Persentase \\
\hline SD Sederajat & 18 & $44 \%$ \\
\hline SMP & 13 & $32 \%$ \\
\hline SMA & 8 & $19 \%$ \\
\hline S1 & 2 & $5 \%$ \\
\hline
\end{tabular}

Sumber: Data Primer di Olah, 2018

\section{Data Responden Berdasarkan Usia}

Tabel 2

\section{Data Responden Berdasarkan Usia}

\begin{tabular}{|c|c|c|}
\hline Usia & Jumlah & Persentase \\
\hline 21-30 Tahun & 6 & $15 \%$ \\
\hline 31-40 Tahun & 11 & $27 \%$ \\
\hline 41-50 Tahun & 15 & $36 \%$ \\
\hline >50 Tahun & 9 & $22 \%$ \\
\hline Total & $\mathbf{4 1}$ & $\mathbf{1 0 0 \%}$ \\
\hline
\end{tabular}

Sumber: Data Primer di Olah, 2018

Berdasarkan data yang dipaparkan pada tabel di atas jumlah responden dengan rentang usia 21-30 tahun berjumlah 6 orang dengan persentase $15 \%$. Untuk usia 31-40 tahun berjumlah 11 orang (27\%). Responden dengan usia 41-50 berjumlah 15 orang yang merupakan jumlah tertinggi dengan persentase $36 \%$. Untuk responden dengan usia $>50$ tahun berjumlah 9 orang (22\%).

\section{Data Responden Berdasarkan Lama Kerja}

Tabel 3

Data Berdasarkan lama Bekerja

\begin{tabular}{|l|c|c|}
\hline Lama bekerja & Jumlah & Persentase \\
\hline$<10$ Tahun & 8 & $19 \%$ \\
\hline 11-20 Tahun & 13 & $32 \%$ \\
\hline 21-30 Tahun & 9 & $22 \%$ \\
\hline$>30$ Tahun & 11 & $27 \%$ \\
\hline Total & $\mathbf{4 1}$ & $\mathbf{1 0 0 \%}$ \\
\hline
\end{tabular}

Sumber: Data Primer Di olah, 2018

Berdasarkan data yang dipaparkan di tabel di atas diketahui bahwa responden terbanyak dengan lama bekerja 11 sampai 20 tahun berjumlah 13 orang (32\%), selanjutnya lama bekerja lebih dari 30 tahun berjumlah 
11 orang (27\%), lama bekerja 21 sampai 30 tahun berjumlah 9 orang (22\%) dan lama kerja yang kurang dari 10 tahun berjumlah 8 orang dengan persentase $19 \%$.

\section{Analisis Statistik Deskriptif}

\section{MenurutGhozali (2016:19) StatistikDeskriptif} memberikan gambaran atau deskripsi suatu data yang dilihat dari nilai rata-rata (mean), standar deviasi, maksimum,dan minimum. Adapunvariabel bebas dalam penelitian ini adalah keterampilan kerja, fasilitas kerja dan semangatkerja serta variabel terikatnya adalah produktivitas kerja.Dimana dalam penelitian inimenggunakan 41 responden dengan kuesioner yang berisi pernyataan-pernyataan.

Tabel 4 Hasil Uji Statistik Deskriptif

\begin{tabular}{|l|c|c|c|c|c|}
\hline \multicolumn{5}{|c|}{ Descriptive Statistics } \\
\hline & $\mathrm{N}$ & $\begin{array}{c}\text { Mi } \\
n\end{array}$ & Max & Mean & $\begin{array}{c}\text { Std. } \\
\text { Deviat } \\
\text { ion }\end{array}$ \\
\hline $\begin{array}{l}\text { Keterampila } \\
\text { n Kerja }\end{array}$ & 41 & 11 & 20 & 15,46 & 2,550 \\
\hline $\begin{array}{l}\text { Fasilitas } \\
\text { Kerja }\end{array}$ & 41 & 12 & 30 & 20,85 & 3,575 \\
\hline $\begin{array}{l}\text { Produktivitas } \\
\text { Kerja }\end{array}$ & 41 & 24 & 44 & 33,73 & 4,353 \\
\hline $\begin{array}{l}\text { Valid N } \\
\text { (listwise) }\end{array}$ & 41 & & & & \\
\hline
\end{tabular}

Sumber: Output Data SPSS Versi 24, 2018

Berdasarkan data yang dipaparkan di tabel diatas diketahui bahwa nilai minimumdari keterampilan kerja sebesar (11), maximum sebesar (20), mean sebesar $(15,46)$, dan Std. Deviation sebesar $(2,550)$. Selanjutnya untuk variabel fasilitasminimum sebesar (12), maximum sebesar (30), mean sebesar $(20,85)$, dan Std. Deviation sebesar(3,575). Untuk variabel produktivitas kerja minimum sebesar (24), maximum sebesar (44), mean sebesar $(33,73)$ dan std. deviation sebesar $(4,353)$.

\section{Deskripsi Variabel Keterampilan Kerja}

Variabelketerampilan kerja $\left(\mathrm{X}_{1}\right)$ merupakan variabel pernyataan pertama yang diukur melalui 4 pernyataan yang diuraikan dari indikator-indikator yang digunakan untuk mengukur kualitas keterampilan kerja.Dapat dilihat pada tabel dibawah ini untuk mengetahui persentase skor variabelketerampilan kerja.

\section{KESIMPULAN DAN SARAN}

\section{Kesimpulan}

Berdasarkan hasil analisis dan pembahasan pada bab sebelumnya, maka kesimpulan yang dapat diambil dari penelitian ini adalah sebagai berikut:

1) Pengujian secara parsial membuktikan bahwa keterampilan kerja berpengaruh signifikan terhadap produktivitas kerja nelayan Kampung Bugis dengan nilai perbandingan $t_{\text {hitung }}$ dengan $\mathrm{t}_{\text {tabel }}\left(\mathrm{t}_{\text {tabel }} \alpha=0,05, \mathrm{df}=38\right)$ didapat $\mathrm{t}_{\text {hitung }} 4,089$ lebih besar dari $t_{\text {tabel }} 1,68595 \quad(4,089>1,68595)$ dan nilai probabilitas sebesar $0,000<\operatorname{sig} 0,05$.

2) Pengujian secara parsial membuktikan bahwa fasilitas kerja secara parsial berpengaruh signifikan terhadap produktivitas kerja nelayan Kampung Bugis dengan nilai perbandingan $t_{\text {hitung }}$ dengan $t_{\text {tabel }}\left(t_{\text {tabel }} \alpha=0,05, \mathrm{df}=38\right)$ didapat $t_{\text {hitung }}$ 2,420 lebih besar dari $t_{\text {tabel }} 1,68595 \quad(2,420>$ 1,68595) dan nilai probabilitas sebesar $0,021<$ sig 0,05 .

Pengujian secara simultan membuktikan bahwa keterampilan kerja, fasilitas kerja, semangat kerja, dan jumlah tenaga kerja berpengaruh 
signifikan terhadap produktivitas kerja nelayan Kampung Bugis dengan nilai per-bandingan $\mathrm{F}_{\text {hitung }}$ dengan $\mathrm{F}_{\text {tabel }}\left(\mathrm{t}_{\text {tabel }} \alpha=0,05\right)$ didapat $\mathrm{F}_{\text {hitung }} 8,141$ lebih besar dari $\mathrm{F}_{\text {tabel }} 2,86(8,141>$ 2,86) dan nilai probabilitas sebesar $0,000<$ sig 0,05 .

\section{Saran}

Adapun saran yang dapat diberikan dalam penelitian ini adalah

1) Bagi Pemerintah Daerah setempat diharapkan dapat memberikan pelatihan kepada nelayan secara keseluruhan agar semua nelayan memiliki keterampilan dan kualitas kerja yang lebih baik.

2) Berdasarkan dari hasil penelitian dapat diharapkan kepada para nelayan untuk dapat lebih memahami penggunaan fasilitas peralatan nelayan yang berbasis teknologi sehingga dapat memberikan kontribusi baik terhadap produktivitas kerja.Bagi Pemerintah diharapkan dapat memperhatikan kondisi nelayan denganmemberikan jaminan kesehatan dan keamanan kerja secara menyeluruh untuk nelayan sehingga menimbulkanrasa aman para nelayan terhadap kemungkinan terjadinya resiko kecelakaan kerja.

3) Diharapkan nelayan menyadari dan memperbaiki kesalahan dan kegagalan yang pernah dialami sebelumnya agar semangat kerja timbul kembali sehingga produktivitas kerja ikut meningkat.

4) Pada penelitian selanjutnya diharapkan dapat membahas faktor-faktor lain yang belum diteliti dalam penelitian ini. Dalam penelitian ini variabel yang diteliti hanya terbatas pada pengaruh Keterampilan Kerja dan Fasilitas Semangat Kerja. Sedangkan faktor-faktor lain yang juga berpengaruh terhadap Produktivitas
Kerja yang belum diungkap berapa besar pengaruhnya.

\section{DAFTAR PUSTAKA}

Anam, Khoirul dan Rahardja, Edy. 2017. Pengaruh Fasilitas Kerja, Lingkungan Kerja Non Fisik dan Kepuasan Kerja Terhadap Kinerja Karyawan.Diponegoro Journal of Management.Volume 6, Nomor 4, Tahun 2017, Halaman 1-11. ISSN (Online): 2337-3792

Assagaf, Shannon Cecilia Y. dan Dotulong, Lucky O.H. 2015. Pengaruh Disiplin, Motivasi dan Semangat Kerja Terhadap Produktivitas Kerja Pegawai Dinas Pendapatan Daerah Kota Manado. Jurnal EMBA. ISSN 2303-1174

Badan Perencanaan Pembangunan Daerah. 2018. Bappeda.kepriprov.go.id

Badan Pusat Statistik. Bps.go.id. Produksi Perikanan Tangkap.Di akses 21 November 2018.

Dahlius, Apri dan Ibrahim, Mariaty.2016. Pengaruh Fasilitas Kerja Terhadap Kepuasan Kerja Karyawan Pada Pt. Bank Riaukepri Cabang Teluk Kuantan Kabupaten Kuantan Singingi.JOM FISIP Vol. 3 No. 2 - Oktober 2016

Ghozali, Imam. 2013. Aplikasi Analisis Multivariete dengan Program IBM SPSS 21.Semarang: Badan Penerbit Universitas Diponegoro 2016. Aplikasi Analisis Multivariete dengan Program IBM SPSS 23.Semarang: Badan Penerbit Universitas Diponegoro

Hartatik, Indah Puji. 2014. Buku Praktis Mengembangkan SDM.Jogjakarta: Laksana

Ibrahim, Ilham Fallah. 2018. Pengaruh Keterampilan Kerja, Keselamatan Kerja dan Lingkungan Kerja Terhadap Produktivitas Kerja Karyawan CV Mahesti Jaya Madiun. Ponorogo: Universitas Muhammaddiyah

Kaswan. 2015. Sikap Kerja: Dasar Teori dan Implementasi sampai Bukti. Bandung: Alfabeta

Maisyarah dkk. 2018. Pengaruh Fasilitas, Jumlah Tenaga Kerja, Jam Kerja, dan Pengalaman Kerja Terhadap Produktivitas Kerja Nelayan Kelong pada Kelompok Nelayan Bawal Di Desa $X$. Universitas Maritim Raja Ali Haji

Rachmawati, Fitri dan Sitohang, Sonang. 2014. Pengaruh Lingkungan Kerja, Keterampilan Kerja dan Jenjang Karir Terhadap Kinerja Karyawan. Jurnal Ilmu \& Riset Manajemen Vol. 3 No. 8 (2014) 
Rehman, Abdul dan Mughal Khalid. 2013. Impact of Technical Education on the Labor Productivity. International Journal of Economics, Finance and Management: ISSN 2307-2466

Rusdiana. 2014. Asas-Asas Manajemen Berwawasan Global. Bandung: Cv Pustaka Setia

Sari, Ratna. 2016. Pengaruh Kemampuan Manajemen Camat dan Keterampilan Kerja Terhadap Produktivitas Kerja Pegawai Di Kantor KecamatanSamarinda Ilir.eJournal Pemerintahan Integratif, 2016, 4 (4) : 534-546 ISSN 2337-8670

Sari, Ulfa Purnama. 2016. Pengaruh Fasilitas, Lingkungan Kerja Dan Motivasi Terhadap Kinerja Pegawai Di Kantor Camat Sangatta Selatan Kabupaten Kutai Timur. eJournal Pemerintahan Integratif, Volume 4, Nomor 4

Sarwono, Jonathan. 2014. Teknik Jitu Memilih Prosedur Analisis Skripsi. Jakarta: PT Elex Media Komputindo

Sayoto, Budi dan Winarto, Herry.2018. Pengaruh Disiplin Kerja dan Fasilitas Kerja Terhadap Produktivitas Kerja Karyawan Mnctv Bagian Produksi.ISSN: 2338-4794, Vol.6. No. 2 MeiAgustus 2018

Setiyaningrum, Ika. 2017. Pengaruh Disiplin, Fasilitas Kerja dan Pelatihan Karyawan Terhadap Produktivitas Kerja Karyawan Pada Bank SyariahStudi Kasuspada Bank Mandiri Syariah Kc Kendal. Skripsi IAIN Salatiga

Shaban, Osama Samih. 2017.The Effect of Low Morale and Motivation on Employees' Productivity \& Competitiveness in Jordanian Industrial Companies. International Business Research: ISSN 1913-9004

Siregar, Syofian. 2014. Statistik Parametik untuk Penelitian Kuantitatif: Dilengkapi dengan Perhitungan Manual dan Aplikasi SPSS Versi 17. Jakarta: PT Bumi Aksara

Sugiyono. 2017. Metode Penelitian Kuantitatif, Kualitatif, dan $R \& D$ cetakan ke 25. Bandung: Alfabeta, cv

Sunyoto, Danang. 2013. Metodologi Penelitian Akuntansi. Bandung: PT Refika Aditama. 